Article

\title{
Enhancing hydrothermal stability of nano-sized HZSM-5 zeolite by phosphorus modification for olefin catalytic cracking of full-range FCC gasoline
}

\author{
Yun Zhao, Jiaxu Liu, Guang Xiong, Hongchen Guo * \\ Department of Catalytic Chemistry and Engineering \& State Kay Laboratory of Fine Chemicals, Dalian University of Technology, Dalian 110624, Liaoning, \\ China
}

\section{A R T I C L E I N F O}

\section{Article history:}

Received 20 September 2016

Accepted 14 October 2016

Published 5 January 2017

\section{Keywords:}

Hydrothermal stability

Nano-sized HZSM-5

Phosphorus modification

Olefin catalytic cracking

FCC gasoline

\begin{abstract}
A B S T R A C T
In this study, phosphorus modification by trimethyl phosphate impregnation was employed to enhance the hydrothermal stability of nano-sized HZSM-5 zeolites. A parallel modification was studied by ammonium dihydrogen phosphate impregnation. The modified zeolites were subjected to steam treatment at $800{ }^{\circ} \mathrm{C}$ for $4 \mathrm{~h}(100 \%$ steam) and employed as catalysts for olefin catalytic cracking (OCC) of full-range fluid catalytic cracking (FCC) gasoline. X-ray diffraction, $\mathrm{N}_{2}$ physical adsorption and $\mathrm{NH}_{3}$ temperature-programmed desorption analysis indicated that, although significant improvements to the hydrothermal stability of nano-sized HZSM-5 zeolites can be observed when adopting both phosphorus modification strategies, impregnation with trimethyl phosphate displays further enhancement of the hydrothermal stability. This is because higher structural crystallinity is retained, larger specific surface areas/micropore volumes form, and there are greater numbers of surface acid sites. Reaction experiments conducted using a fixed-bed micro-reactor (catalyst $/$ oil ratio $=4$, time on stream $=4 \mathrm{~s}$ ) showed OCC of full-range FCC gasoline-under a fluidized-bed reaction mode configuration-to be a viable solution for the olefin problem of FCC gasoline. This reaction significantly decreased the olefin content in the full-range FCC gasoline feed, and specifically heavy-end olefins, by converting the olefins into value-added $\mathrm{C}_{2}-\mathrm{C}_{4}$ olefins and aromatics. At the same time, sulfide content of the gasoline decreased via a non-hydrodesulfurization process. Nano-sized HZSM-5 zeolites modified with trimethyl phosphate exhibited enhanced catalytic performance for OCC of full-range FCC gasoline.
\end{abstract}

(C) 2016, Dalian Institute of Chemical Physics, Chinese Academy of Sciences. Published by Elsevier B.V. All rights reserved.

\section{Introduction}

Hydrothermal stability is one of the most important properties that influence the application of zeolitic catalysts. It is well-known that the hydrothermal stability of a zeolitic material depends mainly on its topological structure and framework silica-to-alumina ratio (SAR). However, hydrothermal stability is also significantly influenced by zeolite crystal size. Typically, large-pore zeolites possessing low SARs and nano-particle sizes have poor hydrothermal stability. Conversely, small- and medium-pore zeolites having high SARs and large crystal sizes have improved hydrothermal stability. Although the unique medium-pore MFI structure and high-silica framework composition gives ZSM-5 zeolites excellent hydrothermal stability,

\footnotetext{
* Corresponding author. Tel./Fax.:+86-411-84986120; E-mail: hongchenguo@163.com

This work was supported by the National Natural Science Foundation of China (21603023), and the PetroChina Innovation Foundation, China (2014D-5006-0501).

DOI: 10.1016/S1872-2067(16)62579-2 | http://www.sciencedirect.com/science/journal/18722067 | Chin. J. Catal., Vol. 38, No. 1, January 2017
} 
efforts to further enhance ZSM-5 hydrothermal stability are certainly meaningful for practical uses, especially when subjecting nano-sized ZSM-5 to harsh hydrothermal conditions to applications such as fluidized catalytic cracking (FCC), where the catalyst is required to withstand steaming treatment at $>700{ }^{\circ} \mathrm{C}$. Several techniques have been developed hitherto for enhancing zeolite hydrothermal stability. For example, rare earth ion exchange [1-3], dealumination and silicon-addition by $\left(\mathrm{NH}_{4}\right)_{2} \mathrm{SiF}_{6}$ modification $[4,5]$, and high-temperature steam calcination [6-8] are applied to low silica type zeolites such as $\mathrm{X}$ and Y. Additionally, phosphorus modification by $\mathrm{H}_{3} \mathrm{PO}_{4}$, $\left(\mathrm{NH}_{4}\right)_{2} \mathrm{HPO}_{4}$ or $\mathrm{NH}_{4} \mathrm{H}_{2} \mathrm{PO}_{4}$ impregnation has been proposed for high SAR zeolites, such as $\beta$ and ZSM-5 [9-13]. Multiple strategies are available for improving the hydrothermal stability of low SAR zeolites. However, few approaches are known for high SAR zeolites. As for ZSM- 5 zeolite, phosphorus modification with $\mathrm{H}_{3} \mathrm{PO}_{4}$, $\left(\mathrm{NH}_{4}\right)_{2} \mathrm{HPO}_{4}$ or $\mathrm{NH}_{4} \mathrm{H}_{2} \mathrm{PO}_{4}$ does not always result in satisfactory improvement to hydrothermal stability, and there are few published reports detailing hydrothermal stability enhancement of nano-sized ZSM-5 zeolites.

Gasoline obtained from FCC processes account for a major proportion of the Chinese gasoline pool and generally contains high sulfide and olefin content. To conform to international gasoline standards, the China $\mathrm{V}$ gasoline standard has been issued to meet the necessary specifications and will be implemented in 2017. Stringent threshold levels governed by the China V gasoline standard state that the sulfur content should be $\leq 10 \mu \mathrm{g} / \mathrm{g}$, and olefin content $\leq 24$ vol.\%. Therefore, China has a long-term requirement to upgrade FCC gasoline by decreasing sulfide and olefin content. Currently, the 'S-zorb' process configured within a fluidized bed reactor has been accepted by many large-scale refineries for FCC gasoline desulfurization. In this process, the sulfides in FCC gasoline are removed by selective adsorption over a selective adsorbent. Thereafter, the adsorbent is regenerated to recover the adsorption capacity. The 'S-zorb' process is efficient for the deep desulfurization of FCC gasoline. However, it is unaffordable for smaller refineries. Therefore, hydrodesulfurization will continue to be an important alternative to the 'S-zorb' process. There already exist several well-known hydrodesulfurization processes for FCC gasoline, such as 'SCANfining' and 'Prime G+'. Although these processes are able to simultaneously reduce sulfide and olefin content, hydrodesulfurization usually suffers from relatively big research octane number (RON) loss owing to the hydrogenation saturation of olefins. This problem is of concern in the case of deep hydrodesulfurization. Additionally, the removal of extra olefins from FCC gasoline via hydrogenation is too expensive because of considerable $\mathrm{H}_{2}$ consumption.

In previous studies [14-16], we introduced a fixed-bed olefin-to-aromatics (OTA) reaction using modified nano-sized ZSM-5 zeolites to reduce olefin content in full-range FCC gasoline. The transformation of olefins into aromatics via the OTA reaction was considered as an alternative solution to the olefin problem of FCC gasoline, as aromatics have a higher RON rating than olefins, and the process does not require the consumption of $\mathrm{H}_{2}$ if the FCC-OTA gasoline is not hydrodesulfurized down-stream. However, the economic viability of the OTA reac- tion being implemented within industry is limited because of low OTA conversion and fast catalyst deactivation when set-up in a fixed-bed operation mode. Further potential restrictions will arise if future legislated threshold levels of aromatics in gasoline are lowered. For these reasons, we are now interested in studying the viability of olefin catalytic cracking (OCC) of full-range FCC gasoline with nano-sized ZSM-5 zeolites when configured within a fluidized-bed. The objective is to efficiently transform the extra olefins in FCC gasoline into value-added short-chain olefins like ethylene, propylene and butenes, and to direct the FCC-OCC gasoline for further hydrodesulfurization treatment. Employing nano-sized ZSM-5 zeolites as the catalyst is likely to benefit OCC of full-range FCC gasoline by enhanced performance, however, it is important to improve the hydrothermal stability of nano-sized ZSM-5 zeolites, suitably for fluidized-bed configuration, as if the crystal size is ultrafine the inherent stability of the ZSM-5 structure will weaken.

Therefore, this study is two-fold: first, enhancing the hydrothermal stability of nano-sized ZSM- 5 zeolites by a novel phosphorus modification route featuring trimethyl phosphate and, second, the evaluation OCC of full-range FCC gasoline when employing the stabilized zeolite catalysts under fluidized-bed configuration.

\section{Experimental}

\subsection{Catalyst preparation}

Nano-sized NaZSM-5 powder $\left(20-50 \mathrm{~nm}, \mathrm{SiO}_{2} / \mathrm{Al}_{2} \mathrm{O}_{3}=26\right)$ was supplied by Dalian Ligong Qiwangda Chemical Technology. First, the received zeolite was calcined in a muffle furnace in the presence of static air to remove the organic template. Thereafter, the template-free zeolite was treated by a conventional ammonia ion exchange method to obtain HZSM-5. Further modification of the zeolite was performed by introducing 0.2 wt.\%, 0.6 wt.\%, 1.0 wt.\%, 2.0 wt.\%, and 3.0 wt.\% phosphorus into the HZSM-5 zeolite by incipient wet impregnation via an aqueous solution of trimethyl phosphate $\left(\left(\mathrm{CH}_{3}\right)_{3} \mathrm{PO}_{4}\right)$ at room temperature. For the purpose of comparison, the same phosphorus modifications were repeated with ammonium dihydrogen phosphate $\left(\mathrm{NH}_{4} \mathrm{H}_{2} \mathrm{PO}_{4}\right)$. The modified catalysts were denoted as $0.2 \mathrm{P}(\mathrm{Z})-3.0 \mathrm{P}(\mathrm{Z})$ for $\left(\mathrm{CH}_{3}\right)_{3} \mathrm{PO}_{4}$-modified zeolites, and $0.2 \mathrm{P}(\mathrm{Y})-3.0 \mathrm{P}(\mathrm{Y})$ for $\mathrm{NH}_{4} \mathrm{H}_{2} \mathrm{PO}_{4}$-modified analogues. To investigate changes to hydrothermal stability of HZSM-5 zeolites as a function of phosphorus content and type, the phosphorus-modified catalysts were further steam treated at $800{ }^{\circ} \mathrm{C}$ for $4 \mathrm{~h}(100 \%$ steam $)$. The steamed samples were given a "-st" postfix to the original catalyst codes. All catalysts were pressed, crushed and sieved to 40-60 mesh sizes for reaction purpose.

\subsection{Characterization}

Chemical composition of the catalyst samples was analyzed using a Bruker SRS 3400 X-ray fluorescence (XRF) spectrometer. X-ray diffraction (XRD) was performed using a Rigaku D/MAX-2004 diffractometer with $\mathrm{Cu} K a$ radiation $(40 \mathrm{kV}, 100$ 
$\mathrm{mA}$ ) at a scanning rate of $0.02^{\circ} / \mathrm{min}(2 \theta)$. The relative crystallinity (RC) of the modified samples was obtained by comparing the sum of intensities of its five characteristic peaks at $2 \theta=$ $8^{\circ}-9^{\circ}$ and $23^{\circ}-25^{\circ}$ with that of the precursor. Nitrogen adsorption measurements were conducted at $-196{ }^{\circ} \mathrm{C}$ employing a Micrometrics ASAP 2020 instrument. Before measurements, the samples were subjected to vacuum treatment at $350{ }^{\circ} \mathrm{C}$ for $6 \mathrm{~h}$. The specific surface area was calculated using the classical Brunauer-Emmett-Teller (BET) model, while the pore volume was calculated using the t-plot method. Ammonia temperature-programmed desorption ( $\mathrm{NH}_{3}$-TPD) was performed on a CHEMBET-3000 (Quantachrome) apparatus. Typically, $0.15 \mathrm{~g}$ sample was used for each measurement. First, the sample was purged with $\mathrm{He}$ at $600{ }^{\circ} \mathrm{C}$ for $1 \mathrm{~h}$. Thereafter, the pretreated sample was subjected to $\mathrm{NH}_{3}$ adsorption at $150{ }^{\circ} \mathrm{C}$ until saturation, followed by a He sample sweep at $150{ }^{\circ} \mathrm{C}$ for at least 30 min to expel physically adsorbed $\mathrm{NH}_{3}$. Finally, the $\mathrm{NH}_{3}$ desorption profile was recorded during sample heating from 150 to $600{ }^{\circ} \mathrm{C}$ at a rate of $15^{\circ} \mathrm{C} / \mathrm{min}$ in a He flow $80 \mathrm{ml} / \mathrm{min}$. The relative acid concentrations of the modified samples were estimated from the areas of their desorption profiles, in reference to a precursor. Weak acid concentrations were determined by the desorption profile area in the temperature range of $150-400{ }^{\circ} \mathrm{C}$. Correspondingly, strong acid concentrations were determined by the desorption profile area in the temperature range of $400-600{ }^{\circ} \mathrm{C}$. IR spectra were recorded on a Nicolet 6700 FT-IR spectrometer at room temperature, the spectral resolution was $4 \mathrm{~cm}^{-1}$. To obtain the spectra, the catalysts were pressed into self-supporting thin wafers and activated in a quartz IR cell equipped with $\mathrm{CaF}_{2}$ windows. Activation was performed at $400^{\circ} \mathrm{C}$ for $4 \mathrm{~h}$ under vacuum $\left(10^{-3} \mathrm{~Pa}\right)$. Ammonia adsorption was performed at room temperature for $30 \mathrm{~min}$ at a flow rate of $30 \mathrm{ml} / \mathrm{min}$. After adsorption, samples were evacuated at $150{ }^{\circ} \mathrm{C}$ for $30 \mathrm{~min}$ to remove physically adsorbed ammonia.

\subsection{Reaction evaluation}

A fixed-bed micro-reactor was used to simulate the fluidized-bed reaction configuration for OCC of full-range FCC gasoline. Reactor dimensions were $10 \mathrm{~mm}$ inner diameter and $4.8 \mathrm{~g}$ catalyst loading capacity. The reaction was conducted at $540{ }^{\circ} \mathrm{C}$. The full-range FCC gasoline contained 50.80 wt.\% olefins, 20.82 wt.\% aromatics, 7.69 wt.\% $n$-paraffins, 16.59 wt.\% $i$-paraffins, $3.45 \%$ naphthenes and $675 \mu \mathrm{g} / \mathrm{g}$ sulfur. The feed was pumped in a closed-circuit system with a sampling loop. A desired amount of oil was fed into the micro-reactor via the sampling loop when a six-way valve was manually rotated. The catalyst/oil mass ratio was set to 4 in this study. Using $\mathrm{N}_{2}$ as a diluent gas, the contact time of the feed oil with the catalyst was adjusted to $\sim 4 \mathrm{~s}$. The products from the reactor were cooled using an ice-bath and collected as gaseous and liquid fractions. The liquid fraction was analyzed by a Shimadzu GC-14C gas chromatograph (OV-1 capillary column $50 \mathrm{~m} \times 0.2 \mathrm{~mm}$, FID detector), while the gas fraction was analyzed by a Techcomp 7890F gas chromatograph (PLOT $\mathrm{Al}_{2} \mathrm{O}_{3}$ capillary column $50 \mathrm{~m}$ $\times 0.53 \mathrm{~mm}$, FID detector). The product yield (Y) and selectivity
(S) were calculated on the basis of mass balance as follows: $Y / \%=$ product mass $/$ feed mass $\times 100$

$S / \%=$ product mass $/$ (feed mass - liquid product mass $) \times 100$

Additionally, sulfur content of the feed oil and product oils were measured by coulometry. Oil RON was calculated according to a previously published method [17].

\section{Results and discussion}

\subsection{Enhancing hydrothermal stability of nano-sized HZSM-5 zeolites through phosphate modification}

\subsubsection{Chemical composition of steamed nano-sized HZSM-5 zeolites}

Table 1 shows the compositions of the steamed catalysts studied. The catalysts modified with ammonium dihydrogen phosphate or trimethyl phosphate show no significant compositional changes when compared with the steamed HZSM-5 (NZ-st) catalyst.

\subsubsection{Steamed nano-sized HZSM-5 zeolite crystallinity}

Fig. 1 indicates that, when the parent nano-sized HZSM-5 zeolite was directly subjected to the harsh steaming treatment (100\% steam, $800{ }^{\circ} \mathrm{C}$ for $4 \mathrm{~h}$ ), the RC fell to $\sim 70 \%$. Treatment of the parent zeolite by $\mathrm{NH}_{4} \mathrm{H}_{2} \mathrm{PO}_{4}$ and $\left(\mathrm{CH}_{3}\right)_{3} \mathrm{PO}_{4}$ impregnation and subsequent steaming under the same conditions resulted in higher RC. These results clearly show the effectiveness of phosphorus modification to enhance hydrothermal stability of nano-sized HZSM-5 zeolites. Furthermore, it can be seen that $P$ loading has a significant influence on the resulting degree of crystallinity. The optimum P loading was estimated to be $\sim 0.6$ wt.\% for $\mathrm{NH}_{4} \mathrm{H}_{2} \mathrm{PO}_{4}$, and $\sim 1.0$ wt.\% for $\left(\mathrm{CH}_{3}\right)_{3} \mathrm{PO}_{4}$. By comparison, it is easy to see that modification with $\left(\mathrm{CH}_{3}\right)_{3} \mathrm{PO}_{4}$ results in higher framework integrity than that with $\mathrm{NH}_{4} \mathrm{H}_{2} \mathrm{PO}_{4}$ and therefore better protects the framework of nano-sized HZSM-5 zeolites from the damage of high-temperature steaming.

\subsubsection{Textural properties of the steamed nano-sized HZSM-5 zeolites}

Table 2 shows that, both $\mathrm{NH}_{4} \mathrm{H}_{2} \mathrm{PO}_{4}$, and $\left(\mathrm{CH}_{3}\right)_{3} \mathrm{PO}_{4}$ modifications reduce the specific surface area of the nano-sized HZSM-5 zeolite even though the P loading was limited to 3 wt.\%. Considering the changes of micropore surface area and

\section{Table 1}

Chemical composition of steamed nano-sized HZMS-5 zeolite and the phosphorus-impregnated steamed analogues.

\begin{tabular}{lcccc}
\hline \multirow{2}{*}{ Sample } & \multicolumn{4}{c}{ Content (wt.\%) } \\
\cline { 2 - 5 } & $\mathrm{Al}$ & $\mathrm{Si}$ & $\mathrm{O}$ & $\mathrm{P}$ \\
\hline NZ-st & 2.67 & 44.31 & 52.93 & 0 \\
0.6P(Y)-st & 2.74 & 43.99 & 52.65 & 0.57 \\
1.0P(Y)-st & 2.73 & 43.85 & 52.48 & 0.88 \\
2.0P(Y)-st & 2.47 & 43.62 & 52.00 & 1.85 \\
3.0P(Y)-st & 2.59 & 43.08 & 51.47 & 2.78 \\
0.6P(Z)-st & 2.75 & 43.95 & 52.65 & 0.58 \\
1.0P(Z)-st & 2.57 & 43.98 & 52.49 & 0.90 \\
2.0P(Z)-st & 2.55 & 43.58 & 51.98 & 1.81 \\
3.0P(Z)-st & 2.45 & 43.22 & 51.50 & 2.76 \\
\hline
\end{tabular}



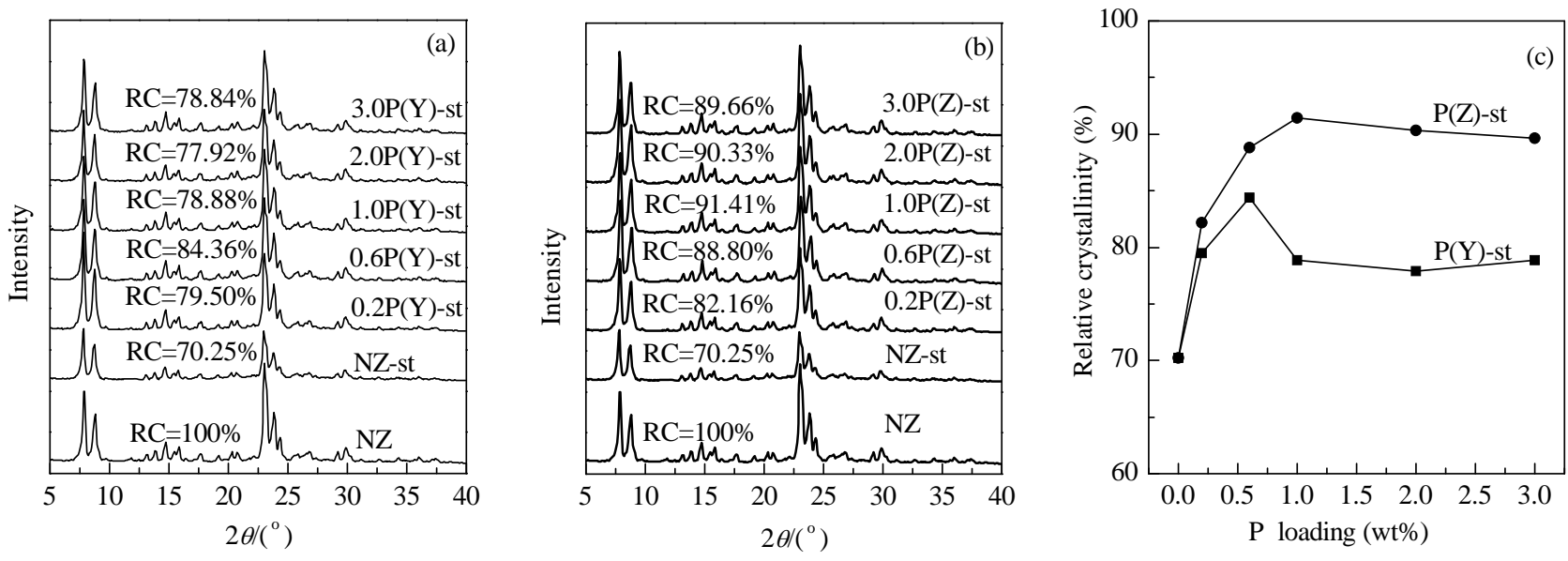

Fig. 1. Effects of different phosphorus modifications on the hydrothermal stability of nano-sized HZSM-5 crystal structure. (a) X-ray diffraction (XRD) patterns along with relative crystallinities (RC) of the parent, steamed and $\mathrm{NH}_{4} \mathrm{H}_{2} \mathrm{PO}_{4}$-modified and steamed zeolites; (b) (CH3) 3 PO $\mathrm{O}_{4}$-modified analogues of (a); (c) RC of the steamed nano-sized HZSM-5 as a function of P loading.

Table 2

Textural properties of nano-sized HZSM-5 and $\mathrm{NH}_{4} \mathrm{H}_{2} \mathrm{PO}_{4}(\mathrm{Y})$ - and $\left(\mathrm{CH}_{3}\right)_{3} \mathrm{PO}_{4}(\mathrm{Z})$-modified counterparts.

\begin{tabular}{lcccccc}
\hline Sample & $\begin{array}{c}S_{\text {BET }} / \\
\left(\mathrm{m}^{2} / \mathrm{g}\right)\end{array}$ & $\begin{array}{c}S_{\text {Micro }} / \\
\left(\mathrm{m}^{2} / \mathrm{g}\right)\end{array}$ & $\begin{array}{c}S_{\text {Exter }} / \\
\left(\mathrm{m}^{2} / \mathrm{g}\right)\end{array}$ & $\begin{array}{c}V_{\text {Total }} / \\
(\mathrm{ml} / \mathrm{g})\end{array}$ & $\begin{array}{c}V_{\text {Micro }} \\
(\mathrm{ml} / \mathrm{g})\end{array}$ & $\begin{array}{c}V_{\text {meso }} / \\
(\mathrm{ml} / \mathrm{g})\end{array}$ \\
\hline $\mathrm{NZ}$ & 348 & 264 & 84 & 0.237 & 0.113 & 0.124 \\
$0.6 \mathrm{P}(\mathrm{Y})$ & 317 & 236 & 80 & 0.225 & 0.102 & 0.123 \\
$1.0 \mathrm{P}(\mathrm{Y})$ & 321 & 240 & 81 & 0.228 & 0.103 & 0.125 \\
$3.0 \mathrm{P}(\mathrm{Y})$ & 312 & 231 & 81 & 0.229 & 0.100 & 0.129 \\
$0.6 \mathrm{P}(\mathrm{Z})$ & 323 & 242 & 81 & 0.230 & 0.104 & 0.126 \\
$1.0 \mathrm{P}(\mathrm{Z})$ & 325 & 238 & 87 & 0.238 & 0.103 & 0.135 \\
$3.0 \mathrm{P}(\mathrm{Z})$ & 327 & 236 & 91 & 0.237 & 0.102 & 0.135 \\
\hline
\end{tabular}

pore volume, both $\mathrm{NH}_{4} \mathrm{H}_{2} \mathrm{PO}_{4}$, and $\left(\mathrm{CH}_{3}\right)_{3} \mathrm{PO}_{4}$ predominately modify the micropores of the nano-sized zeolite. Fig. 2 shows that, as expected, both $\mathrm{NH}_{4} \mathrm{H}_{2} \mathrm{PO}_{4}$ and $\left(\mathrm{CH}_{3}\right)_{3} \mathrm{PO}_{4}$ modifications are helpful in stabilizing the pore structures of nano-sized HZSM-5 zeolite. As a result, the modified zeolites had higher retention rates for surface area and pore volume. Complementary to $\mathrm{RC}$, these correlations also indicated the advantage of $\left(\mathrm{CH}_{3}\right)_{3} \mathrm{PO}_{4}$ over $\mathrm{NH}_{4} \mathrm{H}_{2} \mathrm{PO}_{4}$ for zeolite modification.

\subsubsection{Acidity of steamed nano-sized HZSM-5 zeolites}

Table 3

Relative acidity of nano-sized HZSM-5 and $\mathrm{NH}_{4} \mathrm{H}_{2} \mathrm{PO}_{4}(\mathrm{Y})$ - and $\left(\mathrm{CH}_{3}\right)_{3} \mathrm{PO}_{4}$ (Z)-modified counterparts.

\begin{tabular}{lccc}
\hline Sample & Weak acid & Strong acid & Total acid \\
\hline NZ & 52.61 & 47.39 & 100 \\
$0.2 \mathrm{P}(\mathrm{Y})$ & 52.27 & 41.23 & 93.50 \\
$0.6 \mathrm{P}(\mathrm{Y})$ & 40.42 & 37.68 & 78.10 \\
$1.0 \mathrm{P}(\mathrm{Y})$ & 38.06 & 30.72 & 68.78 \\
$2.0 \mathrm{P}(\mathrm{Y})$ & 23.47 & 23.33 & 46.80 \\
$3.0 \mathrm{P}(\mathrm{Y})$ & 20.19 & 14.96 & 35.15 \\
$0.2 \mathrm{P}(\mathrm{Z})$ & 36.56 & 30.03 & 66.59 \\
$0.6 \mathrm{P}(\mathrm{Z})$ & 37.02 & 26.13 & 63.15 \\
$1.0 \mathrm{P}(\mathrm{Z})$ & 25.74 & 23.25 & 48.99 \\
$2.0 \mathrm{P}(\mathrm{Z})$ & 25.23 & 21.42 & 46.66 \\
$3.0 \mathrm{P}(\mathrm{Z})$ & 28.42 & 13.27 & 41.69 \\
\hline
\end{tabular}

Table 3 indicates that, both $\mathrm{NH}_{4} \mathrm{H}_{2} \mathrm{PO}_{4}$ and $\left(\mathrm{CH}_{3}\right)_{3} \mathrm{PO}_{4}$ modifications significantly reduce the concentration of both weak acid and strong acid sites. This suggests interaction of the phosphorous species with framework $\mathrm{Al}$ present in the modified zeolites. Fig. 3(a) shows that, $\left(\mathrm{CH}_{3}\right)_{3} \mathrm{PO}_{4}$ modification resulted in a faster decrease in the total acid concentration when compared with $\mathrm{NH}_{4} \mathrm{H}_{2} \mathrm{PO}_{4}$ modification when the $\mathrm{P}$ loading was below 2.0 wt.\%. Conversely, increasing the P loading beyond
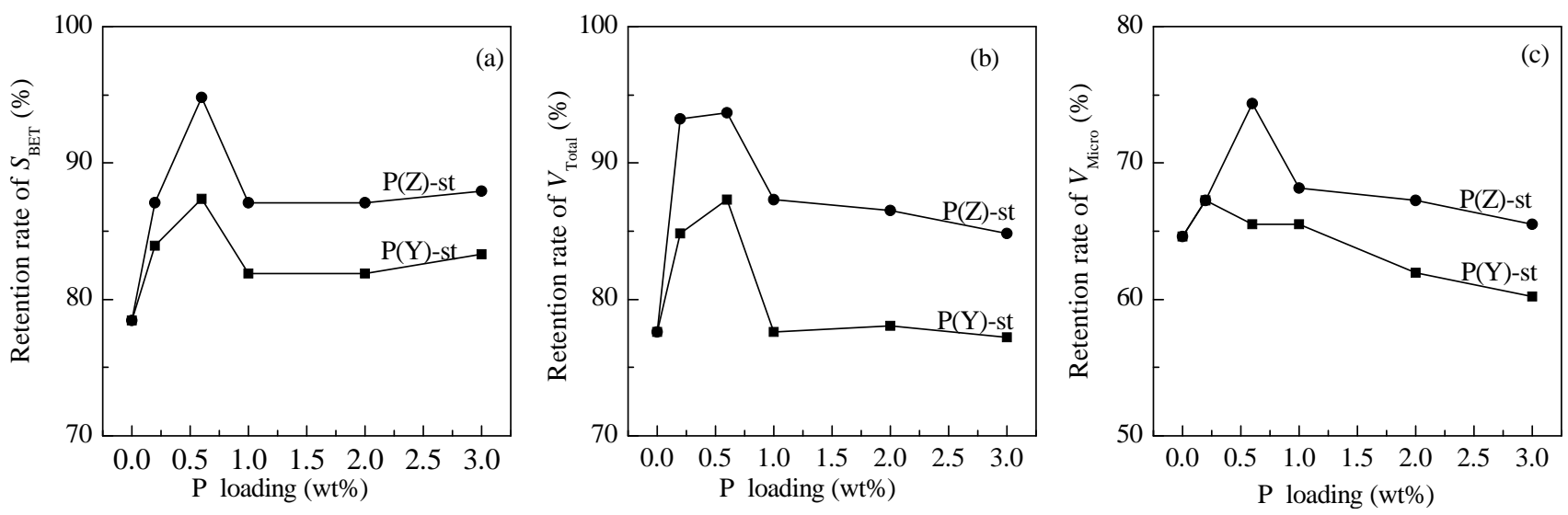

Fig. 2. Effects of $\mathrm{NH}_{4} \mathrm{H}_{2} \mathrm{PO}_{4}(\mathrm{Y})$ and $\left(\mathrm{CH}_{3}\right)_{3} \mathrm{PO}_{4}(\mathrm{Z})$ modifications on the textural properties of the nano-sized HZSM-5 zeolite during subsequent steaming. Retention rate dependence of: (a) total specific area $\mathrm{S}_{\mathrm{BET}}$, (b) total pore volume and (c) micropore volume as a function of $\mathrm{P}$ loading. 

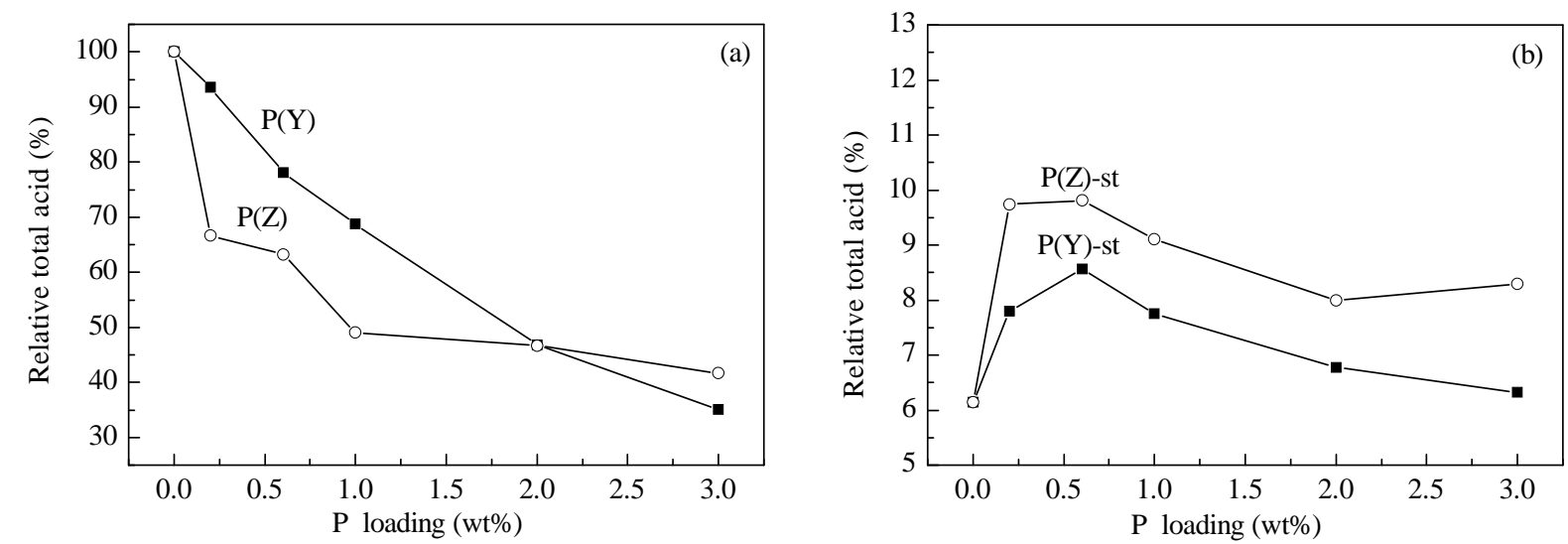

Fig. 3. Effects of $\mathrm{NH}_{4} \mathrm{H}_{2} \mathrm{PO}_{4}(\mathrm{Y})$ and $\left(\mathrm{CH}_{3}\right)_{3} \mathrm{PO}_{4}(\mathrm{Z})$ modifications on the acidity of nano-sized HZSM-5 zeolite. Dependence of relative total acid of nano-sized HZSM-5 zeolite as a function of $\mathrm{P}$ loading (a) before and (b) after high-temperature steaming.
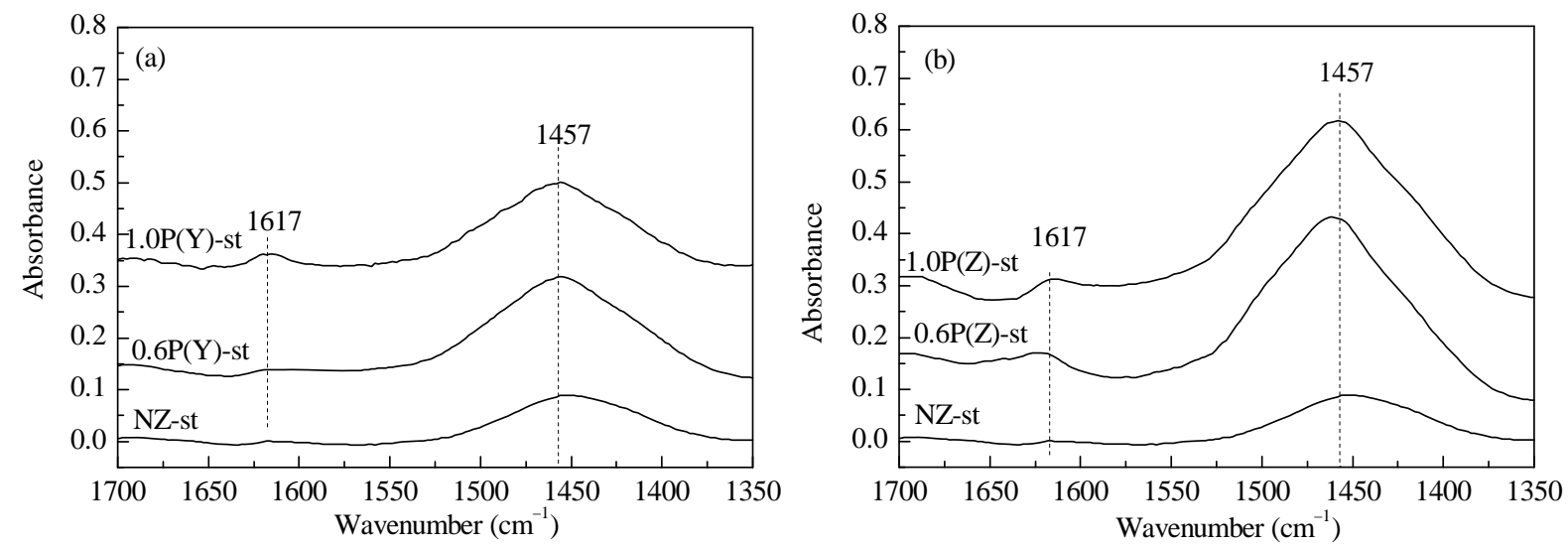

Fig. 4. Ammonia-FT-IR spectra of steam-treated modified nano-sized $\mathrm{HZSM}-5$ zeolites by (a) $\mathrm{NH}_{4} \mathrm{H}_{2} \mathrm{PO}_{4} \mathrm{impregnation}_{\text {, and }}(\mathrm{b})\left(\mathrm{CH}_{3}\right)_{3} \mathrm{PO} \mathrm{impregation}_{4}$

2.0 wt.\%, $\mathrm{NH}_{4} \mathrm{H}_{2} \mathrm{PO}_{4}$, not $\left(\mathrm{CH}_{3}\right)_{3} \mathrm{PO}_{4}$, modification resulted in a faster decrease in the total acid concentration. This phenomenon implies that, for the interaction with framework $\mathrm{Al}$ sites, $\left(\mathrm{CH}_{3}\right)_{3} \mathrm{PO}_{4}$ was more selective and efficient than $\mathrm{NH}_{4} \mathrm{H}_{2} \mathrm{PO}_{4}$. From Fig. 3(b) it can be seen that both $\mathrm{NH}_{4} \mathrm{H}_{2} \mathrm{PO}_{4}$ and $\left(\mathrm{CH}_{3}\right)_{3} \mathrm{PO}_{4}$ modifications enabled far more acid sites in the nano-sized zeolite to be retained after severe high-temperature steaming treatment. Once again, $\left(\mathrm{CH}_{3}\right)_{3} \mathrm{PO}_{4}$ acts as a more fa- vorable precursor as a modifier as compared with $\mathrm{NH}_{4} \mathrm{H}_{2} \mathrm{PO}_{4}$.

In addition to the $\mathrm{NH}_{3}$-TPD acidity characterization, FT-IR spectroscopy was also used to determine the nature of the acid sites within different modified catalysts. In Fig. 4, absorbance peaks located at $1457 \mathrm{~cm}^{-1}$ and $1617 \mathrm{~cm}^{-1}$ belong to Brönsted acids and Lewis acids, respectively. It is evident that regardless of the $\mathrm{P}$ precursor employed in the modification the resulting acidity of the final catalysts is dominated by Brönsted acid sites.
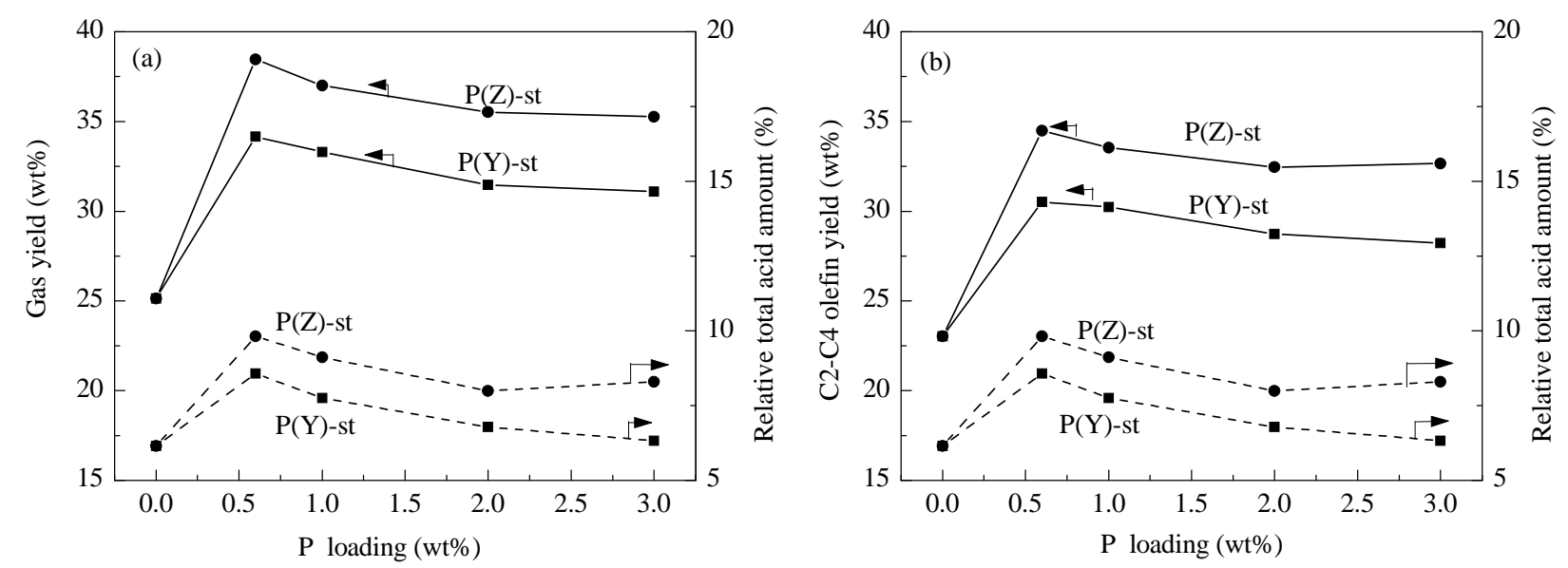

Fig. 5. Relationship between total catalyst acid concentration of $\mathrm{NH}_{4} \mathrm{H}_{2} \mathrm{PO}_{4}(\mathrm{Y})$ - and $\left(\mathrm{CH}_{3}\right)_{3} \mathrm{PO}_{4}$ (Z)-modified nano-sized $\mathrm{HZSM}-5$ zeolites and (a) gas product yield, and (b) $\mathrm{C}_{2}-\mathrm{C}_{4}$ olefin yield from OCC of full-range FCC gasoline. 
Table 4

Gas product distribution from OCC of full-range FCC gasoline over modified nano-sized HZSM-5 zeolites.

\begin{tabular}{|c|c|c|c|c|c|c|c|}
\hline Catalyst & $\begin{array}{l}\mathrm{C}_{1}{ }^{0}+\mathrm{C}_{2}{ }^{0} \\
\text { (wt.\%) }\end{array}$ & $\begin{array}{c}\mathrm{C}_{2}= \\
\text { (wt.\%) }\end{array}$ & $\begin{array}{c}\mathrm{C}_{3}{ }^{0} \\
\text { (wt. \%) }\end{array}$ & $\begin{array}{c}\mathrm{C}_{3}= \\
\text { (wt.\%) }\end{array}$ & $\begin{array}{c}\mathrm{C}_{4}{ }^{0} \\
\text { (wt.\%) }\end{array}$ & $\begin{array}{c}\mathrm{C}_{4}= \\
\text { (wt.\%) }\end{array}$ & $\begin{array}{c}\mathrm{S}\left(\mathrm{C}_{2}=-\mathrm{C}_{4}=\right) \\
\text { (wt.\%) }\end{array}$ \\
\hline NZ-st & 0.23 & 2.60 & 0.8 & 13.37 & 0.52 & 7.05 & 91.53 \\
\hline $0.6 \mathrm{P}(\mathrm{Y})-\mathrm{st}$ & 0.36 & 4.29 & 1.42 & 17.25 & 1.86 & 8.97 & 89.34 \\
\hline 1.0P(Y)-st & 0.20 & 4.00 & 1.04 & 17.54 & 0.72 & 8.69 & 90.78 \\
\hline 2.0P(Y)-st & 0.19 & 4.08 & 1.02 & 16.05 & 0.76 & 8.61 & 91.33 \\
\hline 3.0P(Y)-st & 0.19 & 4.11 & 1.75 & 15.91 & 0.93 & 8.21 & 90.77 \\
\hline $0.6 \mathrm{P}(\mathrm{Z})-\mathrm{st}$ & 0.52 & 4.82 & 1.87 & 18.89 & 1.58 & 10.77 & 89.67 \\
\hline 1.0P(Z)-st & 0.34 & 4.35 & 1.14 & 19.96 & 0.85 & 9.24 & 90.65 \\
\hline 2.0P(Z)-st & 0.26 & 5.31 & 1.37 & 18.13 & 0.91 & 9.02 & 91.36 \\
\hline 3.0P(Z)-st & 0.30 & 5.95 & 1.50 & 17.90 & 1.18 & 8.80 & 92.57 \\
\hline
\end{tabular}

\subsection{OCC of full-range FCC gasoline over phosphorus-modified nano-sized HZSM-5 zeolites}

As mentioned above, $\left(\mathrm{CH}_{3}\right)_{3} \mathrm{PO}_{4}$ modification allows the steamed nano-sized HZSM-5 zeolites to retain more crystallinity, micropores and surface acid sites (mainly Brönsted acid sites) on the whole. Therefore, it is of interest to investigate the catalytic performance of the $\left(\mathrm{CH}_{3}\right)_{3} \mathrm{PO}_{4}$-modified catalysts in OCC of full-range FCC gasoline. For the purpose of comparison, the catalytic performance of the $\mathrm{NH}_{4} \mathrm{H}_{2} \mathrm{PO}_{4}$-modified catalysts is also included in this section.

Fig. 5 shows that, after hydrothermally treatment at $800{ }^{\circ} \mathrm{C}$ for $4 \mathrm{~h}$ under a $100 \%$ steam atmosphere, the parent nano-sized HZSM-5 zeolite has rather low catalytic cracking activity. Consequently, gas and $\mathrm{C}_{2}-\mathrm{C}_{4}$ olefin yields over the parent zeolite were only $\sim 25 \%$ and $23 \%$, respectively. However, both $\left(\mathrm{CH}_{3}\right)_{3} \mathrm{PO}_{4}$ and $\mathrm{NH}_{4} \mathrm{H}_{2} \mathrm{PO}_{4}$ modifications significantly increased the catalytic cracking activity of the nano-sized HZSM-5 zeolite. As a result, the gas and $\mathrm{C}_{2}-\mathrm{C}_{4}$ olefin yields over the modified zeolite catalysts notably increased to $\sim 38 \%$ and $\sim 35 \%$, respectively, with $\left(\mathrm{CH}_{3}\right)_{3} \mathrm{PO}_{4}$-modified HZSM-5, and $\sim 34 \%$ and $\sim 30 \%$, respectively, with $\mathrm{NH}_{4} \mathrm{H}_{2} \mathrm{PO}_{4}$-modified HZSM-5. All improved yields reached a maximum at a P loading of $0.6 \mathrm{wt} \%$. It is evident that the variation in yield trend follows the trend of relative total acid concentration in the catalysts, which is a function of phosphorus loading, therefore the acidity of the catalyst plays a key role in the reaction. Furthermore, the

\section{Table 5}

Comparison of full-range FCC gasoline (feed) and corresponding catalytically cracked oil products obtained over different nano-sized HZSM-5 zeolite catalysts.

\begin{tabular}{lccccc}
\hline Catalyst & $\begin{array}{c}Y_{\text {oil }} \\
\text { (wt.\%) }\end{array}$ & $\begin{array}{c}\text { Olefins } \\
\text { (wt.\%) }\end{array}$ & $\begin{array}{c}\text { Aromatics } \\
\text { (wt.\%) }\end{array}$ & $\begin{array}{c}\text { RON (cal- } \\
\text { culated) }\end{array}$ & $S(\mu \mathrm{g} / \mathrm{g})$ \\
\hline Feed & 100.00 & 50.40 & 21.52 & 94.2 & 675 \\
NZ-st & 74.85 & 40.10 & 38.18 & 98.4 & 322 \\
\hline $0.6 P(Y)-s t$ & 65.85 & 27.05 & 51.02 & 97.8 & 180 \\
1.0P(Y)-st & 66.70 & 27.53 & 49.06 & 97.1 & 180 \\
2.0P(Y)-st & 68.53 & 29.45 & 48.54 & 96.8 & 200 \\
3.0P(Y)-st & 68.90 & 31.51 & 45.35 & 96.2 & 204 \\
\hline 0.6P(Z)-st & 60.70 & 27.45 & 52.95 & 97.8 & 185 \\
1.0P(Z)-st & 62.99 & 27.09 & 49.93 & 97.5 & 183 \\
2.0P(Z)-st & 64.47 & 28.53 & 48.62 & 96.5 & 198 \\
3.0P(Z)-st & 64.73 & 29.14 & 48.93 & 97.5 & 190 \\
\hline
\end{tabular}

$\left(\mathrm{CH}_{3}\right)_{3} \mathrm{PO}_{4}$-modified nano-sized HZSM-5 zeolite catalysts have a clear activity advantage over the $\mathrm{NH}_{4} \mathrm{H}_{2} \mathrm{PO}_{4}$-modified catalysts as a result of increased acid site retention.

Table 4 indicates that, OCC over different modified catalysts gave similar gas products. For example, the gas products contained $\sim 90 \% \mathrm{C}_{2}=-\mathrm{C}_{4}=$, the content of propylene was approximately 3-5 times that of ethylene and double the concentration of butenes. However, only when OCC of full-range FCC gasoline was performed in the presence of phosphorus-modified catalysts could the olefin content in the product oils be reduced to less than 30\%-far below the olefin content of the gasoline feed (Table 5). That means, the phosphorus-modified catalysts had stronger olefin-reduction ability. Undoubtedly, this should be attributed to the enhanced hydrothermal stability of the nano-sized HZSM-5 zeolites as a result of phosphorus modification, which allowed the catalysts to retain a higher degree of Brönsted acid sites after high-temperature steaming. Additionally, a significant increase in the aromatic content in the product oils was observed, which increased from $21.52 \%$ in a $100 \%$ gasoline feed to $\sim 50 \%$ in a $60-70 \%$ product oil. This indicates substantial aromatization occurring during the OCC when configured in a fluidized-bed operation mode. Aromatization is thought to proceed via hydrogen transfer by the Brönsted acid-catalyzed carbenium ion-chain mechanism. With respect to RON rating of the product oils, OCC benefits from this concurrent reaction. The calculated data suggests that the product oils of the OCC should have improved anti-knock properties. Additionally, a significant decrease in the sulfide content from 675 $\mu \mathrm{g} / \mathrm{g}$ in the gasoline feed to less than $200 \mu \mathrm{g} / \mathrm{g}$ in the product oils can be found when OCC is performed in the presence of phosphorus-modified catalysts, which corresponded to at least

\section{Table 6}

Light and heavy olefin conversion comparison during OCC of full-range FCC gasoline over different nano-sized HZSM- 5 zeolite catalysts.

\begin{tabular}{lcc}
\hline Catalyst & $\begin{array}{c}\text { Conversion of } \\
\text { light olefins }\left(\mathrm{C}_{4}=-\mathrm{C}_{6}=\right)\end{array}$ & $\begin{array}{c}\text { Conversion of } \\
\text { heavy olefins }\left(\mathrm{C}_{7}=-\mathrm{C}_{12}=\right.\end{array}$ \\
\hline NZ-st & 366.81 & 45.75 \\
\hline $0.6 \mathrm{P}(\mathrm{Y})$-st & 60.65 & 70.52 \\
1.0P(Y)-st & 59.99 & 68.78 \\
2.0P(Y)-st & 57.70 & 63.24 \\
3.0P(Y)-st & 55.33 & 59.25 \\
\hline $0.6 \mathrm{P}(\mathrm{Z})-\mathrm{st}$ & 64.49 & 70.52 \\
1.0P(Z)-st & 62.43 & 71.56 \\
2.0P(Z)-st & 59.63 & 69.17 \\
3.0P(Z)-st & 59.05 & 67.71 \\
\hline
\end{tabular}



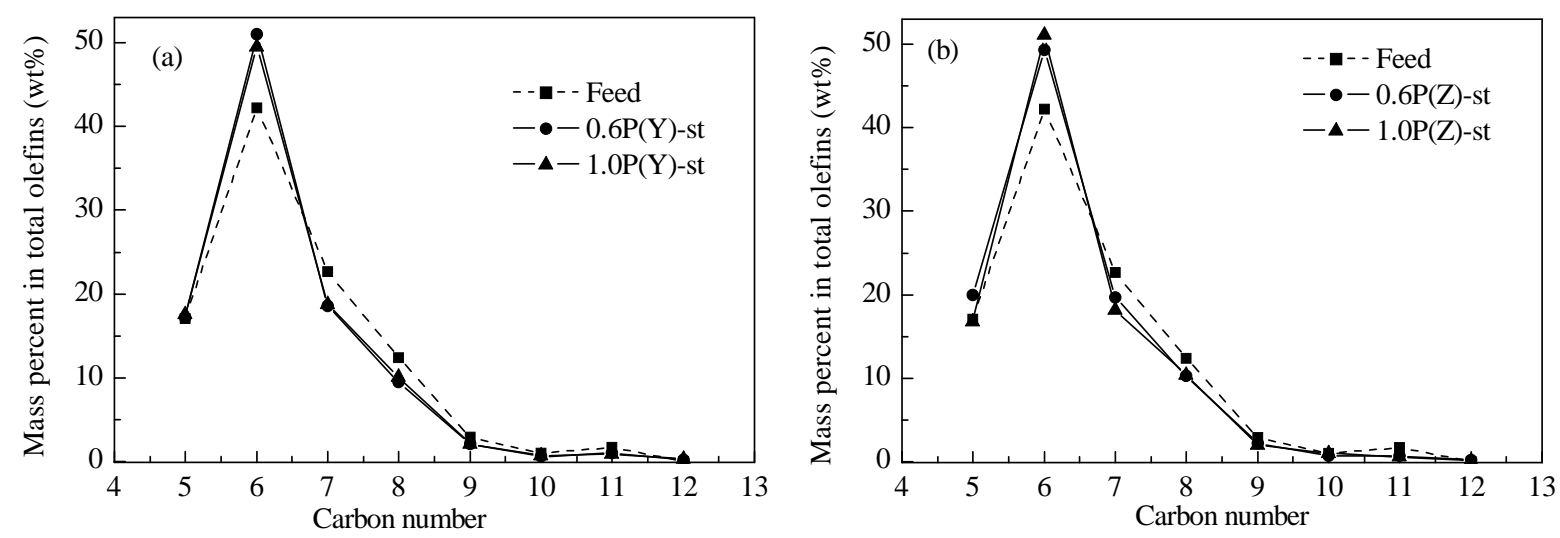

Fig. 6. Olefin carbon number distributions of the full-range FCC feed oil (dotted line) and product oils from OCC of full-range FCC gasoline over (a) $\mathrm{NH}_{4} \mathrm{H}_{2} \mathrm{PO}_{4}(\mathrm{Y})$ - and (b) $\left(\mathrm{CH}_{3}\right)_{3} \mathrm{PO}_{4}(\mathrm{Z})$-modified nano-sized HZSM-5 zeolites (full lines).

an $80 \%$ desulfurization rate. Obviously, non-hydrodesulfurization should be an additional advantage of OCC, by significant $\mathrm{H}_{2}$ savings, thus allowing subsequent hydrodesulfurization easier. Furthermore, from Table 6 and Fig. 6 it can be seen that, OCC converted more heavy olefins than light olefins. As a result, the carbon number distribution of olefins in the product oils were shifted towards shorter-chain olefins as compared with that in the full-range FCC gasoline feed. This would facilitate the subsequent hydrodesulfurization as if the product oils from the OCC of full-range FCC gasoline, termed FCC-OCC gasoline, is fractionated into light and heavy cuts, in the following hydrodesulfurization process, the heavy end would contain less olefins and thus high hydrodesulfurization selectivity is expected.

\section{Conclusions}

This study shows that $\left(\mathrm{CH}_{3}\right)_{3} \mathrm{PO}_{4}$ impregnation is an effective phosphorus modification method for enhancing the hydrothermal stability of nano-sized HZSM-5 zeolites. Low phosphorus loading is sufficient for the ultra-fine zeolite to withstand severe steaming treatment and to retain high crystallinity, large specific area and micropore volume, and abundant surface acid sites. It is believed that $\left(\mathrm{CH}_{3}\right)_{3} \mathrm{PO}_{4}$ modification may open further opportunities for nano-sized HZSM-5 zeolites to act as efficient catalysts for reactions occurring under harsh hydrothermal conditions. Preliminary analysis in OCC of full-range FCC gasoline confirms the significance of the $\left(\mathrm{CH}_{3}\right)_{3} \mathrm{PO}_{4}$ modification. Furthermore, when the OCC of full-range FCC gasoline is configured in a fluidized bed reaction mode, it may offer an alternative solution for the olefin problem of FCC gasoline upgrade.

\section{References}

[1] Y. Y. Shu, A. Travert, R. Schiller, M. Ziebarth, R. Wormsbecher, W. C. Cheng, Top. Catal., 2015, 58, 334-342.

[2] E. F. Sousa-Aguiar, F. E. Trigueiro, F. M. Z. Zotin, Catal. Today, 2013, 218-219, 115-122.

[3] X. H. Du, X. H. Gao, H. T. Zhang, X. L. Li, P. S. Liu, Catal. Commun, 2013, 35, 17-22.

[4] G. W. Skeels, D. W. Bred, in: D. Olson, A. Bisio, eds, Proceedings of 6th International Zeolite Conference, Reno, USA, 1983, 87.

[5] D. W. Breck, H. Blass, G. W. Skeels, US Patent 4503 023, 1985.

[6] W. K. T. Gleim, US Patent 3293 172, 1966.

[7] P. K. Maher, C. V. McDaniel, US Patent 3402 996, 1968.

[8] C. V. McDaniel, P. K. Maher, US Patent 3449 070, 1969.

[9] A. Yamaguchi, D. F. Jin, T. Ikeda, K. Sato, N. Hiyoshi, T. Hanaoka, F. Mizukami, M. Shirai, Catal. Commun., 2015, 69, 20-24.

\section{Graphical Abstract}

Chin. J. Catal., 2017, 38: 138-145 doi: 10.1016/S1872-2067(16)62579-2

Enhancing hydrothermal stability of nano-sized HZSM-5 zeolite by phosphorus modification for olefin catalytic cracking of full-range FCC gasoline

Yun Zhao, Jiaxu Liu, Guang Xiong, Hongchen Guo* Dalian University of Technology

Phosphorus modification of nano-sized HZSM- 5 zeolite by trimethyl phosphate impregnation was employed to enhance hydrothermal stability of the zeolites, which exhibited excellent catalytic performance for the olefin catalytic cracking of full-range fluid catalytic cracking gasoline.

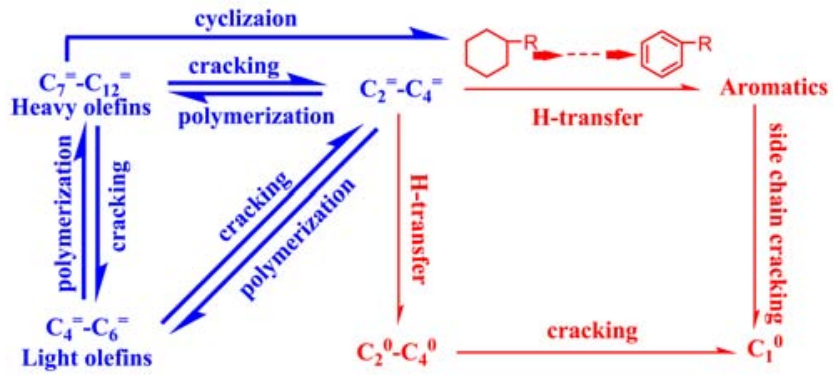


[10] J. Ding, M. Wang, L. M. Peng, N. H. Xue, Y. M. Wang, M. Y. He, Appl. Catal. A, 2015, 503, 147-155.

[11] T. Blasco, A. Corma, J. Martinez-Triguero, J. Catal., 2006, 237, 267-277.

[12] N. H. Xue, X. K. Chen, L. Nie, X. F. Guo, W. P. Ding, Y. Chen, M. Gu, Z. K. Xie, J. Catal., 2007, 248, 20-28.

[13] C. X. Xie, J. Zhao, H. F. Pan, S. K. Ning, Petrochem. Techno., 2002, 31, 691-695.
[14] P. Q. Zhang, X. W. Guo, H. C. Guo, X. S. Wang, J. Mol. Catal. A, 2007, 261,139-146.

[15] H. Y. Long, F. Y. Jin, G. Xiong, X. S. Wang, Microporous Masoporous Mater., 2014, 198, 29-34.

[16] X. B. Zhao, X. W. Guo, X. S. Wang, Energy Fuels, 2006, 20, 1388-1391.

[17] N. Nikolaou, C. E. Papadopoulos, I. A. Gaglias, K. G. Pitarakis. Fuel, 2004, 83, 517-523.

\title{
磷改性纳米HZSM-5沸石水热稳定性及其对全馏分FCC汽油烯烃组分催化裂解反 应的性能
}

\author{
赵云, 刘家旭, 熊 光, 郭洪臣* \\ 大连理工大学化工学院催化化学与工程系精细化工国家重点实验室
}

\begin{abstract}
摘要: 水热稳定性是决定沸石分子笁工业应用价值的重要影响因素. 众所周知, 沸石材料的水热稳定性主要受其拓扑机构 及骨架硅铝组成的影响, 但同时也受其晶粒尺寸的影响. 纳米级HZSM-5沸石虽然具有优异的催化性能及抗积碳失活性能, 但由于晶粒尺寸较小, 导致其水热稳定性较差. 如何提高纳米HZSM-5沸石的水热稳定性, 使其能够在高苛刻度的水热环 境下 (如催化裂化过程, 催化剂再生需在高于 $700^{\circ} \mathrm{C}$ 的水热条件下进行)得到应用, 是十分有意义的课题. 已有研究表明, 磷 改性可以提高ZSM-5沸石的水热稳定性, 但多集中于采用磷酸、磷酸氢二铵、磷酸二氢铵等无机磷化物进行改性, 水热稳 定性提高效果不能令人满意. 我们研究组采用有机磷化合物磷酸三甲酯改性纳米HZSM-5沸石, 在提高纳米HZSM-5沸石 水热稳定性方面取得了较好的效果. 采用 X射线衍射 $(\mathrm{XRD})$ 、氨气程序升温脱附 $\left(\mathrm{NH}_{3}-\mathrm{TPD}\right)$ 、氮气物理吸附、氨气吸附红 外光谱等手段对改性沸石进行了表征. 结果表明, 采用磷酸三甲酯改性的纳米HZSM-5沸石水热稳定性得到明显提高, 沸 石经苛刻的高温水蒸气处理 $\left(800^{\circ} \mathrm{C}, 4 \mathrm{~h}\right)$ 后, 在相对结晶度、孔结构、酸度的保留度方面具有较大提高, 提高幅度明显高于 无机磷化合物磷酸氢二铵改性的纳米HZSM-5沸石.

在上述研究基础上, 我们采用固定床微反模拟流化床反应条件对磷改性纳米HZSM-5沸石上全馏分FCC汽油烯烃组分 催化裂解反应进行了研究. 结果表明, 在反应温度 $540^{\circ} \mathrm{C}$, 剂/油比等于 4 , 油剂接触时间约为 $4 \mathrm{~s}$ 的条件下, 全馏分FCC汽油 在磷改性纳米HZSM-5沸石上经烯烃组分催化裂解反应后, 油品烯烃含量(尤其是重烯烃)明显降低, 生成了大量高附加值 的 $\mathrm{C}_{2}-\mathrm{C}_{4}$ 烯烃, 同时油品中芳烃含量增加. 与此同时, 经烯烃组分裂解后的油品还呈现出辛烷值升高, 硫含量降低的有利变 化. 可以看出, 磷改性纳米HZSM-5沸石上全馏分FCC汽油烯烃组分催化裂解是解决FCC汽油烯烃含量高的一条有效途径, 充分克服了现有FCC汽油加工工艺存在的一些缺陷, 如S-zorb工艺功能单一、成本高; 加氢脱硫工艺油品辛烷值损失大、 氢耗高; 以及OTA技术(本研究组之前的工作)烯烃转化率低、催化剂积碳失活快等缺陷. 值得注意的是, 磷酸三甲酯改性 的纳米HZSM-5沸石在全馏分FCC汽油烯烃组分催化裂解反应性能方面, 明显比磷酸二氢铵改性的纳米HZSM-5沸石表现 优异. 通过我们的研究可以认为, 磷酸三甲酯改性将会为纳米HZSM-5沸石在高苛刻度水热条件下的应用提供更多的机会.
\end{abstract} 关键词: 水热稳定性; 纳米HZSM-5; 磷改性; 烯烃催化裂解; FCC汽油

收稿日期: 2016-09-20. 接受日期: 2016-10-14. 出版日期: 2017-01-05.

*通讯联系人. 电话/传真: (0411)84986120; 电子信箱: hongchenguo@163.com

基金来源：国家自然科学基金(21603023)和中国石油科技创新基金(2014D-5006-0501).

本文的英文电子版由Elsevier出版社在ScienceDirect上出版(http://www.sciencedirect.com/science/journal/18722067). 